\title{
THE ROLE OF NONMETROPOLITAN ECONOMIC PERFORMANCE IN RISING PER CAPITA INCOME DIFFERENCES AMONG THE STATES
}

\author{
John M. Redman, Thomas D. Rowley, and John Angle*
}

\begin{abstract}
This paper examines two phenomena of the 1980s-the rapid divergence of state per capita incomes and the generally weak performance of the rural economy-to see if and how the two are related. First, states most responsible for income divergence are identified, and several popular notions regarding the sources of growing inequality are tested. Next, the importance of relative metro/nonmetro performance to divergence is examined. A central finding is that the 1980 s ended with an acute income imbalance between richer, primarily Atlantic Coast states with largely urban populations and poorer, mostly central or southeastem states, which are heavily nonmetropolitan. The nonmetro economies of these poorer states exhibited much greater structural weakness during the 1980s than did their metro counterparts. Barring a substantial decline in per capita income among the richer states, significant reduction of interstate inequality will thus require particularly strong improvement of nonmetro performance within the poorer, heavily rural states.
\end{abstract}

\section{INTRODUCTION}

Overall economic performance in the nonmetropolitan United States was persistently worse than that of the metropolitan United States during the 1980s. Nonmetro employment and income growth rates significantly lagged metro rates, and many rural areas experienced very high rates of net population out-migration. These persistent differences go beyond what might be attributed to the farm crisis of the 1980s and are products of broader structural weaknesses in the rural economy.

The 1980s were also a decade of increasing inequality among state per capita incomes-a reversal of historic trends. Were the two phenomena related?

In this paper, we provide an overview of the rise in per capita income inequality and then focus on the role of rural economic performance in producing the increase. In general, the data strongly suggest that any one "conventional wisdom" regarding the rise in regional inequality during the 1980 s is much too coarse to capture what is clearly a more complex dynamic. The data also strongly suggest, however, that the rapid rise in inequality during the 1980s was associated with a striking polarization between rural states and urban states in terms of per capita income.

*Economic Research Service, U.S. Department of Agriculture. 


\section{THE RAPID RISE IN STATE PER CAPITA INCOME INEQUALITY DURING THE 1980S}

For nearly 50 years, differences among state per capita incomes decreased. Beginning in 1979, however, the trend reversed. State per capita incomes diverged rapidly. By 1989, one measure of inequality-the coefficient of variationhad increased 41 percent over its 1979 value to its highest level in more than 20 years. $^{1}$

The potential impacts of continuing divergence could include increasingly disparate standards of living and widening differences in fiscal capacities of state and local governments, thus increasing differences in levels of public service provision, most notably long-term capital investment central to sustained economic vitality. Ultimately, the obvious decline in equity could be accompanied by declines in national productivity.

\section{Review of Recent Findings}

Several authors have examined the recent rise in per capita income inequality for possible causes. Amos $(1985,1989)$ investigated the phenomenon from four theoretical viewpoints-neoclassical, export base, cumulative causation, and growth pole-and found that none satisfactorily explained the resurgence of inequality. Instead, he found promise in the ability of long wave theory and in the rise of technological innovation to explain unbalanced growth and the resulting inequality. Coughlin and Mandelbaum $(1988,1989)$ identified specific states responsible for the increase in inequality and tested for the influence of regional changes, commodity prices, and federal fiscal policy on the increase. Of these possible causes, they found that falling energy prices, which drove down earnings in energy-dependent states, had the largest effect. In a regional level analysis, Browne (1989) concluded that changes in relative earnings per job were the primary source of relative changes in regional per capita income in both the 1970s and 1980s. These changes were attributable mainly to changes in earnings in individual industries rather than to shifts in industry mix. Garnick $(1990,34)$ found that "income that is related to jobs" (that is, earnings), rather than unearned income, accounted for "the bulk of the change in regional per capita personal income as a percent of the national average."

Building on these works, Rowley, Redman, and Angle (1991) estimated the relative effect on this increase of change in the interstate equality of each component of per capita income. In addition, the authors explored the association between industrial specialization and the rise in inequality. A synopsis of those findings is presented in the next section. 
State performance and increasing inequality. Coughlin and Mandelbaum (1988) categorized states according to growth in real per capita income relative to the national mean. States in which real per capita income increased (decreased) toward the mean during 1979-89 are classified as upwardly (downwardly) convergent. States in which real income increased (decreased) away from the mean are labeled upwardly (downwardly) divergent. ${ }^{2}$ States in which income changed less than 5 percentage points in either direction are deemed to have had no significant change (see Figure 1).

By definition, states in the divergent groups increased national inequality. Convergent states contributed to increased equality. States with no significant change exercised little influence.

Figure 1 illustrates definite regional patterns to the increasing inequality. Eleven of 15 Atlantic Coast states were upwardly divergent. In fact, all upwardly moving states (divergent and convergent) are on the Atlantic Coast or in New England. The downwardly moving states are all west of the Mississippi River, except for West Virginia.

To estimate the relative contribution of the two groups of divergent states to the increase in the coefficient of variation, we recalculated the increase, excluding each group. Thus, the relative contribution of the downwardly divergent states was estimated by calculating the percentage increase in the coefficient of variation of the 38 states that were not downwardly divergent. The difference between that increase and the increase of the 50-state coefficient is used as a rough measure of the effect on the increase in inequality due to the downwardly divergent states. $^{3}$

The 41 percent increase from 1979 to 1989 in the 50-state coefficient of variation is reduced to 25 percent when the downwardly divergent states are excluded. In contrast, excluding the upwardly divergent states results in a coefficient of variation increase of only 1 percent from 1979 to 1989 . Thus, states that were upwardly divergent had by far the largest effect on the increase in interstate income inequality during the $1979-89$ period.

Similar calculations highlight the strong regional pattern of unbalanced growth. Removing Atlantic Coast states from the calculation of the change in the coefficient of variation holds the increase to 9 percent (compared to 41 percent). This reduction approaches that achieved by removing the upwardly divergent states. ${ }^{4}$ While much has been said and written about the existence of a "bicoastal economy," the Atlantic Coast states (along with Vermont) were clearly the winners in terms of relative per capita income growth.

Income components and increasing inequality. We sought to determine whether change in any one component of per capita income (i.e., per capita earnings, per capita property income, and per capita transfer payments) drove this 


\section{FIGURE 1}

State Per Capita Income Movement with Respect to National Mean, 1979-89

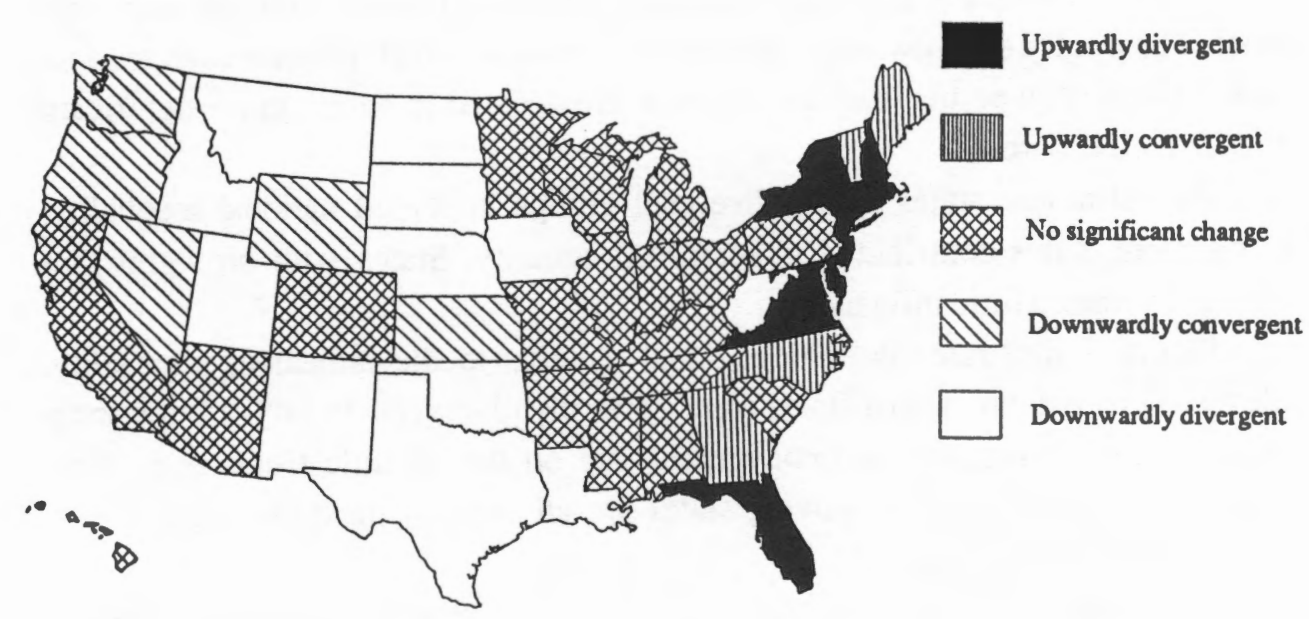

strongly divergent growth pattern. To estimate the relative contribution of each component to the increase in the coefficient of variation, we recalculated the increase three times, each time controlling for one of the components. ${ }^{5}$ The results clearly indicate that changes in earnings per capita contributed the most to changing inequality. Controlling for earnings, the coefficient of variation actually decreased 2 percentage points. Controlling for relative changes in per capita dividends, interest, and rent and, separately, for per capita transfer payments, the coefficient still increases 33 percent and 42 percent, respectively. ${ }^{6}$

Industrial specialization. Some light can be shed on upward and downward divergence through reference to a state's industrial specialization at the beginning of the decade. To explore the association between industrial specialization and increasing inequality, we recalculated change in the coefficient after excluding each of five groups of states (see Table 1). Three groups received particularly high percentages of total 1979 earnings from sectors that experienced economic stress during the 1980s (manufacturing, farming, and energy extraction). The other two groups received particularly high percentages from sectors that experienced strong growth (high-technology manufacturing and producer services). ${ }^{7}$ 
TABLE 1

Effects of Industrial Groups on Increase in PCI Inequality, 1979-89

Percentage Change in Coefficient of Variation

All states

All states except:

Manufacturing

Farming

Energy

High-tech manufacturing

Producer services

This exercise yielded several surprising findings. The group of manufacturing states, as a whole, had little effect on the level of inequality. In fact, only one of the manufacturing states was divergent. This finding does not mean that the problems of manufacturing did not depress rates of income growth in these states, only that performance by other sectors of their economies permitted aggregate state growth near the national average.

The farm states included six of the twelve downwardly divergent states. While the farm crisis contributed to increasing inequality by reducing farm earnings in these downwardly divergent states, the thirteen farm states, as a group, exercised little effect on inequality. Seven of these thirteen states experienced no significant change in their relative income position or were convergent. ${ }^{8}$ In addition, North Dakota and Montana (downwardly divergent) were also energy states; thus, declining farm income was not the sole factor depressing growth in these two states. Overall, then, the farm crisis appears to have had little effect on increasing state per capita income inequality.

Nine of the twelve downwardly divergent states were energy states. Even so, the exclusion of the energy states reduced the rise in inequality by only 10 percentage points. The fall in energy prices, then, does not appear a dominant factor in rising inequality, though it undoubtedly depressed growth in most of the energy states that were downwardly divergent.

The two "high growth" groups explained more of the increase than any of the "downturn" groups, which is consistent with the finding that upward divergence contributed more to rising inequality than downward divergence. Seven of the eleven upwardly divergent states had specializations in producer services. Still, when the producer services states are removed, almost half the coefficient's in- 
crease remains. Specialization in high-tech manufacturing explains less of the increase and applies to only four upwardly divergent states.

To summarize, upward divergence by eleven Atlantic Coast states appears primarily responsible for the rapid increase in state per capita income inequality during the 1980s. Downward divergence by twelve states-almost all in the middle of the country-had a smaller effect. No single economic specialization fully explains this pattern of divergence, though specializations in producer service or high-tech manufacturing come the closest.

We now turn to an additional dimension of the issue: Did very poor (very strong) nonmetro economic performance drive downward (upward) divergence?

\section{NONMETRO PER CAPITA INCOME GROWTH AND INCREASING INEQUALITY}

From 1979 to 1987, more than half of all counties in thirty-seven states experienced a substantial change (either upward or downward) in per capita income relative to the mean of all counties in the United States. This tremendous shift occurred in both metro and nonmetro counties. However, nonmetro counties did significantly worse (see Table 2). Only 16 percent of all nonmetro counties had an increase in per capita income relative to the mean. Nearly twice that percentage of

TABLE 2

Metro and Nonmetro County PCI Performance, 1979-87

\begin{tabular}{lccc}
\hline \hline & \multicolumn{3}{c}{ Percentage of Counties } \\
\cline { 2 - 4 } & $\begin{array}{l}\text { Upwardly } \\
\text { Moving }\end{array}$ & $\begin{array}{c}\text { Downwardly } \\
\text { Moving }\end{array}$ & $\begin{array}{c}\text { No Significant } \\
\text { Change }\end{array}$ \\
\hline Metro & 31 & 29 & 40 \\
Nonmetro & 16 & 43 & 42 \\
\hline
\end{tabular}

metro counties experienced an increase. Similarly, a much higher percentage of nonmetro than metro counties were downwardly moving -43 percent compared to 29 percent. $^{9}$

Despite these differences, however, both metro and nonmetro counties along the Atlantic Coast did well, while west of the Mississippi both did poorly (some even suffered absolute decreases in real per capita income). This similarity in performance of metro and nonmetro counties by region implies that differences in performance were not a major cause of increasing inequality. To test that in- 
ference, we examine the divergent states for significant differences in metro and nonmetro per capita income growth rates.

Nonmetro performance in divergent states. Using the Coughlin/Mandelbaum typology described above, we examine county per capita income growth in the upwardly and downwardly divergent states-the two categories that contributed most to rising inequality. In seven of the nine upwardly divergent states with nonmetro populations, the difference between metro and nonmetro 1979-87 per capita income growth rates averaged less than half a percentage point per year. ${ }^{10}$ In fact, in five of the nine, nonmetro per capita income grew faster than metro. Thus, per capita income growth in most upwardly divergent states was comparably strong in both metro and nonmetro counties.

Among the twelve downwardly divergent states, the metro/nonmetro differences in 1979-87 growth rates were likewise generally small. In only two of these twelve states did this difference exceed a third of a percentage point per year. In seven of the twelve, nonmetro per capita income outperformed metro (that is, had a higher growth rate or a lower rate of decline). Across these states, then, per capita income growth in both metro and nonmetro counties was comparably weak or negative.

In both upwardly and downwardly divergent states, then, the difference between metro and nonmetro per capita income growth was small. Therefore, the difference in metro and nonmetro per capita income growth rates explains little of the increasing state per capita income inequality.

\section{PER CAPITA INCOME: A MISLEADING INDICATOR?}

Small differences between the rates of per capita income change in metro and nonmetro areas should not, however, be interpreted to mean that the economies performed equally well (poorly). If we examine metro/nonmetro differences on several alternative performance measures, namely, earnings and population growth rates and rates of net migration, a very different pattem emerges.

In most of the downwardly divergent states, nonmetro rates of growth in earnings and population were much slower than those in metro counties (see Table 3). Net out-migration was also much higher from nonmetro counties. The small differences in per capita income growth rates appear largely attributable to the offset of weak nonmetro earnings growth by even weaker population growth or, in some cases, absolute population decline. This pattern suggests that the nonmetro economies of these states suffered from much greater underlying structural weaknesses than their metro counterparts. These underlying weaknesses in the 
TABLE 3

Change in PCI, Earnings, Population, and Net Migration, 1979-87

Percentage Change

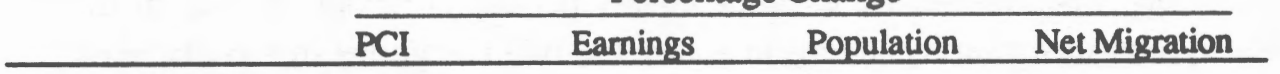

Downwardly Divergent States

$\begin{array}{lrrrr}\text { Metro } & -1.5 & 0.4 & 11.1 & 0.9 \\ \text { Nonmetro } & -1.8 & -9.6 & 4.7 & -4.1\end{array}$

Upwardly Divergent States

\begin{tabular}{llrrr} 
Metro & 22.4 & 29.1 & 8.2 & 5.0 \\
Nonmetro & 22.6 & 28.0 & 10.0 & 8.3 \\
\hline
\end{tabular}

nonmetro economy, as important as they are, are not captured by per capita income growth comparisons. This relationship between earnings and population also helps explain why the decline in farm and energy earnings did not have a stronger effect on changes in state per capita income inequality.

In sharp contrast, nonmetro earnings and demographic performance were better than or similar to metro performance in most of the upwardly divergent states (see Table 3). Thus, in these states, the measures corroborate the findings of the per capita income comparison.

\section{RURAL GROWTH AND THE REDRESS OF INTERSTATE INEQUALITY}

As of 1990, the downwardly divergent states comprise twelve of the poorest twenty states and six of the poorest ten. All experienced very weak growth in per capita income over the last decade, and all but one are located west of the Mississippi. In six of the twelve downwardly divergent states, per capita income has declined to a level equivalent to or below Alabama's-the state ranked 47th in 1979 per capita income and below each of these six at that time. Per capita income in three of the remaining six is now just barely above that of Alabama. ${ }^{11}$ Barring a steep, prolonged recession confined to the Northeast/Mid-Atlantic area, substantially greater interstate income equality requires that performance in these downwardly divergent states improve significantly over the next decade, so much so as to greatly outpace growth among the wealthier states.

But of what importance is rural development to such a turnaround? It seems clear that over the last decade, the nonmetro economy in most of these downwardly divergent states has been much weaker than in its metro counterpart, as il- 
lustrated in Table 3. Nonmetro performance may not be of particular significance, however, if most of the state's population is metropolitan; if so, whatever happens in rural areas is of but marginal significance to the state's future per capita income standing.

This marginality is clearly evident in most of the ten upwardly divergent states, nine of which were among the ten richest in 1989. Nonmetro population in seven of the ten was less than 10 percent of the 1987 total state population; only in New Hampshire did it comprise more than a third (see Table 4). Thus, although nonmetro areas in these states had strong economic and demographic performance similar to that of metro areas, these factors really did not matter much in terms of total state performance.

The situation is very different among the downwardly divergent states, however. The nonmetro population in eight of these twelve states accounted for at least 54 percent of total state population. Texas had the smallest percentage of its population in nonmetro areas, but this population still accounted for 20 percent of the state total. In most of these states, then, nonmetro performance is central to, if not dominant in, overall state performance.

The remaining eight of the twenty poorest states, of which all but Wyoming are in the Southeast, also had large percentages of their population in nonmetro areas. The eight-state mean percentage was 54 percent. Seven of these states failed to significantly improve their per capita income relative to the national mean during the 1979-89 period. Six of the eight also had much slower 1979-87 nonmetro earnings growth than metro earnings growth-a pattern evident in most of the downwardly divergent states. ${ }^{12}$ Across all twenty poorest states, the nonmetro population was on average 55 percent of the state's population, compared with 24 percent among the remaining thirty states. ${ }^{13}$ Clearly, the impact of rural economic performance on overall performance is large in almost all these poorer states.

\section{INTERPRETATION OF RESULTS}

Why did interstate per capita income inequality assume such a strong metro/nonmetro dimension during the 1980s? We hesitate to offer any firm conclusion because the sources of these differences are not well understood. Just ten years ago, rural America was believed to be in the process of "renaissance," a perception sparked by findings that the historical pattern of rural to urban population migration had unexpectedly reversed, and that many nonmetro areas had experienced rapid economic expansion. Just as unexpected was the abrupt reversal of these trends during the 1980s. 
TABLE 4

Nonmetro Population as a Percentage of State Population, 1987

Percent

Upwardly divergent states:

$\begin{array}{lr}\text { Connecticut } & 8.0 \\ \text { Delaware } & 32.9 \\ \text { Florida } & 9.7 \\ \text { Maryland } & 7.0 \\ \text { Massachusetts } & 3.9 \\ \text { New Hampshire } & 40.0 \\ \text { New Jersey } & 0.0 \\ \text { New York } & 9.7 \\ \text { Rhode Island } & 8.6 \\ \text { Virginia } & 30.1 \\ \text { Mean } & 15.0 \\ \text { Median } & 9.2\end{array}$

Downwardly divergent states:

$\begin{array}{ll}\text { Idaho } & 82.0 \\ \text { Iowa } & 58.2 \\ \text { Louisiana } & 31.3 \\ \text { Montana } & 75.6 \\ \text { Nebraska } & 54.8 \\ \text { New Mexico } & 60.6 \\ \text { North Dakota } & 64.4 \\ \text { Oklahoma } & 43.3 \\ \text { South Dakota } & 84.5 \\ \text { Texas } & 20.5 \\ \text { Utah } & 22.7 \\ \text { West Virginia } & 63.2 \\ \text { Mean } & 55.1 \\ \text { Median } & 59.4\end{array}$

Remaining eight of twenty poorest states:

$\begin{array}{ll}\text { Alabama } & 36.0 \\ \text { Arkansas } & 60.5 \\ \text { Kentucky } & 54.2 \\ \text { Mississippi } & 70.0 \\ \text { North Carolina } & 52.8 \\ \text { South Carolina } & 40.0 \\ \text { Tennessee } & 34.6 \\ \text { Wyoming } & 86.4 \\ \text { Mean } & 54.3 \\ \text { Median } & 53.5\end{array}$


Nonetheless, various researchers have identified several factors that exerted powerful influences on this reversal. First, the rapid rise in international commodity prices that occurred during the 1970s did not continue into the 1980s. As noted earlier, commodity price movements do not appear to have driven the rise in interstate income inequality but did contribute to it by depressing earnings growth in many downwardly divergent states.

Second, Reid et al. (1988) argue that decentralization of more standardized, less-skilled manufacturing jobs to lower wage (and less unionized) nonmetro areas-a move that spurred rural growth during the late 1960s and early 1970sslowed or stopped during the 1980 s in the face of deep recession, accelerated automation of production processes, created more efficient management practices, and heightened foreign competition.

Third, central place theory suggests that specialized producer services will tend to concentrate in urbanized areas with (relatively) large populations and economic bases, which implies that growth in producer services-an important contributor to aggregate U.S. growth during the 1980s-would have been much more rapid in metro areas. A recent comparison by Porterfield (forthcoming) of metro/nonmetro service growth supports that notion. Between 1981 and 1987, metro producer service employment grew at almost three times the nonmetro rate (21.3 percent to 8.6 percent).

The position of nonmetro economies in the central place hierarchy may also help explain why they have so far proven largely unattractive to investment in the rapidly growing "high-tech" manufacturing sector. It has been argued that the formation/expansion of such innovation-based industries requires specialized skill pools that are not commonly found in nonmetro areas. Only when the pace of product innovation slows and production becomes more routinized do lower rural wages offer a distinct competitive advantage (Glasmeier 1991).

In general, then, the competitive advantages enjoyed by nonmetro areas, principally greater natural resource endowments and lower labor costs, helped propel growth during the 1970s. During the 1980s, however, these assets commanded much lower premiums. ${ }^{14}$

\section{CONCLUSION}

Beyond the issue of aggregate metro/nonmetro inequality is one of imbalance between richer, primarily Atlantic Coast states with largely urban populations and poorer, mostly central or southeastern states with large (in most cases, majority) nonmetropolitan populations. Many of the richer states enjoyed rapid growth in per capita income during the 1980s. Almost all of the poorer states suf- 
fered much slower-even negative-growth and exhibited particular weakness in their nonmetro economies. Absent a sharp decline in per capita income among the upwardly divergent states, significantly greater interstate income equality will require a marked acceleration of growth by the poorer states. Given that almost all these poorer states have large percentages of their population in nonmetro areas, much faster state growth requires much faster nonmetro growth. Since recent nonmetro performance has been much weaker than metro performance in most of these states, there is no guarantee that strong metro growth will produce satisfactory acceleration of nonmetro growth.

It should be noted that, even if state growth rates converge, absolute income differences may not decrease and could, in fact, continue to increase. For example, the average state in the group of 20 poorest (with 1989 per capita income of about $\$ 13,820$ ) must grow more than 50 percent faster than the average upwardly divergent state (with income of about $\$ 20,900$ ) to avoid falling further behind in absolute dollar terms. The poorer a state is, the faster it must run just to stay in place.

To summarize, the rise in inequality during the 1980s cannot be explained by any one conventional explanation such as the farm crisis, the fall in real energy prices, the decline of the Rust Belt, the rise of high-tech manufacturing, the "Massachusetts Miracle," or the growth of the producer service sector. While each undoubtedly contributed to income divergence, no individual trend was entirely responsible for the rise in inequality. What is clear, however, is that, at the decade's end, per capita incomes were very different between states with large nonmetro populations and those with large metro populations. Relative metro/nonmetro performance during the 1990 s is thus likely to exercise an important influence on how interstate income inequality stands at the turn of the century.

\section{ENDNOTES}

1. Change in inequality as measured by the Gini coefficient, Thiel's index, and the mean absolute deviation yields similar results.

2. States that crossed the mean are classified as divergent (convergent) if they moved further in percentage points away from (toward) than toward (away from) the mean. For example, if a state's per capita income was 104 percent of the national mean in 1979 and 90 percent in 1989, the state ended farther away from the mean than at the beginning of the period and would thus be classified as downwardly divergent. 
3. The relative contribution of state groupings was also estimated by assigning group members the unweighted mean growth rate of nonmember states and then recalculating the percentage increase in the coefficient of variation. Results from the two methods are similar; therefore, we present only the first. Theil's Measure of Inequality and Gini's Concentration Ratio were similarly decomposed using the exclusionary method, and the results were also similar. Therefore, the contribution of state groupings to rising inequality is independent of the measure used.

4. A popular notion is that strong growth in New England, as illustrated by the "Massachusetts Miracle," was a prime factor in increasing inequality. However, removing the New England states reduces the increase by only 8 percentage points to 33 percent. Two of the six New England states (Vermont and Maine) were strongly convergent, offsetting much of the divergent effect of Massachusetts, Connecticut, New Hampshire, and Rhode Island.

5. For example, the effect of per capita earnings on the coefficient of variation was estimated by assigning the 50-state unweighted mean rate of earning growth to each state and recalculating the coefficient's increase.

6. Change in the coefficient of variation due to the components of income was calculated over the $1979-88$ period, as these were the latest available data. The coefficient for total per capita income-the sum of the components-from 1979 to 1988 was 38 percent.

7. The minimum percentage of total state eamings required for inclusion as a "specialized" state included: manufacturing, 12 percent; farm, 4 percent; energy, 3 percent; high-tech manufacturing, 9 percent; and producer services, 9 percent.

8. These seven had a much lower level of initial dependence on agriculture than the downwardly divergent farm states. Thus, if we had defined farm states differently, we would have had somewhat different results.

9. Similar results are obtained if the percentage of metro and nonmetro population living in each of these county groups is substituted for the actual number of counties in each group.

10. New Jersey and the District of Columbia contain only metro populations.

11. These declines were not the result of strong growth in Alabama: the state grew only slightly faster than the 50-state average rate of 12 percent. The more fundamental cause of decline was very poor performance among these downwardly divergent states.

12. The average metro/nonmetro difference in earnings growth among these six (Arkansas, Kentucky, Mississippi, North Carolina, South Carolina, and Tennessee) was 10.8 percentage points with a minimum (Kentucky) of 8.3 percentage points. A seventh state, Wyoming, experienced a general "free-fall" of both metro ( -44 percent) and nonmetro (-20 percent) earnings. 
13. The correlation coefficient between the state proportion of nonmetro population in 1987 and 1989 state per capita income is -.73, indicating a strong inverse relationship between income level and the proportion of nonmetro population.

14. One notable exception has been nonmetro counties that serve as retirement destinations for older Americans. In these counties, amenity values-one type of natural resource endowment-have helped attract greater population and investment.

\section{REFERENCES}

Amos, Orley M., Jr. "Substate and SMSA Personal Income Inequality and Regional Development." The Review of Regional Studies 16 (1985): 3-14. "An Inquiry into the Causes of Increasing Regional Income Inequality in the United States." The Review of Regional Studies 19 (1989): 1-12.

Browne, Lynn E. "Shifting Regional Fortunes: The Wheel Turns." New England Economic Review (May/June 1989): 27-40.

Coughlin, Cletus C., and Thomas B. Mandelbaum. "Why Have State Per Capita Incomes Diverged Recently?" Review of the Federal Reserve Bank of St. Louis (September/October 1988): 24-36.

. "Have Federal Spending and Taxation Contributed to the Divergence of State per Capita Incomes in the 1980's?" Review of the Federal Reserve Bank of St. Louis (July/August 1989): 29-42.

Garnick, Daniel H. "Accounting for Regional Differences in Per Capita Personal Income Growth: An Update and Extension." Survey of Current Business (January 1990): 29-40.

Glasmeier, Amy. The High-Tech Potential: Economic Development in Rural America. New Brunswick, N.J.: Center for Urban Policy Research, Rutgers University, 1991.

Porterfield, Shirley. "Services Producing Industries in the Rural Economy." In Business Assistance Strategies for Rural Development. Economic Research Service, U.S. Department of Agriculture, forthcoming.

Reid, J. Norman, et al. Economic Realities in Rural America: Recent Trends, Future Prospects. Washington, D.C.: National Governors' Association, 1988.

Rowley, Thomas D., John M. Redman, and John Angle. The Rapid Rise in State Per Capita Income Inequality in the 1980's: Sources and Prospects. Economic Research Service, U.S. Department of Agriculture. Staff Report AGES 9104 (January 1991). 